\title{
Beneficial Owners' Interpretation of Implementing Tax Treaties and Implications About the Certainty of Corporate Funding Through Global Bond Issuance: A Case Study of a Decision by the Supreme Court of the Republic of Indonesia
}

\author{
Lastri Defani Sinambela*, Indrayagus Slamet
}

Master of Accounting, Universitas Indonesia Jakarta, Indonesia

*Corresponding author. Email: defasinambela@gmail.com

\begin{abstract}
The purpose of this study is to analyze the beneficial owner interpretation used in the Supreme Court of the Republic of Indonesia's decision Number 133/B/PK/PJK/2017, between PT PLN and DGT, and to assess the implications for Majapahit Holding BV's funding by issuing global bonds. Many cases brought to the tax court involve differences in interpretation, and many companies form SPVs abroad to issue global bonds. Our analysis uses a case study approach, and our qualitative research design incorporates numerous data sources (data triangulation). The study details the consequences of the decision and the rules about beneficial ownership in Indonesia (stated in PER-10/PJ/2017). Different interpretations of beneficial ownership occur because facts about SPVs are missing. The Indonesian tax authorities need to request documents to prove who was the actual beneficial owner. An entity can be established as a beneficial owner if it has fulfilled the requirements contained in the OECD commentary about limitations on benefits.
\end{abstract}

Keywords: Beneficial Owner, Tax Treaty, OECD Commentary

\section{INTRODUCTION}

The literature states that the concept of beneficial owner (BO) derived from English law. An entity has substantive rights to enjoy a property ("ownership rights of trustees," "trusteeship ownership rights," or "ownership rights of beneficiaries"), meaning rights to benefits (Brown, 2003; Meyer, 2010).

In Indonesia, the term beneficial owner was introduced in Article 26, Paragraph (1a), of the 1983 Law Number 7 concerning income tax. The law was amended several times, the latest being Law Number 36 of 2008 (Income Tax Law). Before beneficial owner provisions can become law, the Director General of Taxes, through a circular letter or regulation, tests the beneficial owner economically (Purwijanti, 2018).

Disclosure of beneficial owner information tends to lower a country's economic potential and income, because it allows tax avoidance. As a G20 member country, Indonesia, in 2014, agreed to the High-Level Principle on Beneficial Ownership and Transparency (Toit and Charl, 1999). This principle strongly emphasized the importance of transparency and that accurate beneficial owner information be made available to authorized institutions. The beneficial owner was often called the "Actual Benefits Owner" of a corporation, The ability to access information about beneficial owners was a principal framework of Anti- Income Reduction and Profit Shifting, 
also known as Base Erosion and Profit Shifting (BEPS) (Darussalam et al., 2010; Lelyemin, 2009; Darussalam, 2013).

Cases related to interpreting the definition of beneficial owner often occur in Indonesia. The first case involved PT Indosat Tbk, which established Indosat Finance BV (IFC BV) on October 13, 2003, in Amsterdam. This SPV was created to fund the operational business of PT Indosat Tbk by issuing debt securities. Bonds issued by IFC BV were fully guaranteed by PT Indosat and IFC BV to provide loans to PT Indosat. IFC $\mathrm{BV}$ was only paid legal, professional, administrative, and notary expenses. Interest expense was the most significant burden. Since no salaries were paid, IFC BV had no economic activity. IFC BV was ultimately considered to be a pass-through company, because it enjoyed or controlled interest income received from Indonesia. Legally, IFC BV was required to transfer all interest earned to third parties. In deciding this case, the tax court judge referred to Article 11 of the OECD Model, which states that a conduit company is not considered a beneficial owner. The tax court rejected the appeal and said that interest payments were subject to a $20 \%$ income tax, based on Article 26, because IFC BV was not considered a beneficial owner (Decision court Number, 2008; Decision Court Number PUT-23289/PP/M.II, 2010; Tax court decision 05/Pdt.G, 2003).

This study's specific research object is the payment of interest on PT Perusahaan Lwastrik Negara's (PLN) international bonds to Majapahit Holding BV, which was domiciled in the Netherlands. According to the DGT, Majapahit Holding BV SKD/COD, which was domiciled in the Netherlands, could not be considered a beneficial owner. The real owners of interest income on the international bonds were international bondholders, who live in various countries. Majapahit Holding BV was determined to be a specialized purpose company (SPV/Special Purpose Vehicle), established only to issue international bonds. When examined by the Directorate General of Taxes (KPP), PT PLN was not allowed to deduct the $20 \%$ income tax, because Majapahit Holding BV was not the relevant BO (Tax Court Decision Number 133/B/PK/PJK/2017).

According to PT PLN, however, interest payments were made to Majapahit Finance BV, not to Majapahit Holding BV. PT PLN also determined that, based on the facts, Majapahit Holding (which should be Majapahit Finance BV) was not the beneficial owner of the interest paid by the appellant. The beneficial owner was an international tax language, which was not appropriate if the given term refers to domestic law. Even though in principle Majapahit BV Finance was not a beneficial owner, SPV did not have the right to use and enjoy, but the evidence was still weak, and the DGT's arguments did not convince the judge. Although similar cases can be found, over the last three years, few cases have used the BO argument. Therefore, Tax has begun to use domestic anti-avoidance clauses regarding tax treaty misuse (PER10/2017, formerly PER-62/2011).

In Indonesia, domestic taxpayers form SPVs abroad to obtain less expensive financing through tax savings. The overall cost of debt securities in Indonesia competes with that in the international market. Companies also fund themselves abroad to take advantage of foreign capital markets' greater depth. A WPDN bond issuer wants its bonds to be attractive to investors. However, investors prefer yields with no tax deductions. This encourages companies to set up SPVs in the Netherlands, which is subject to a $0 \%$ tax deduction as long as the SPV (as the income recipient) is the beneficial owner. Previous studies related to beneficial ownership did not highlight this fact. [All things should not only be about taxes but must also provide convenience for the company in developing its business]. Indonesian companies have taken advantage of overseas SPVs to issue bonds. In such cases, the legality rested on the term "beneficial owner".

\section{LITERATURE REVIEW}

\subsection{Study Literature}

An OECD model study by Anggrainy (2014) regarding double tax avoidance agreements stated that determining a beneficial owner was a legal issue. As long as the recipient of the income has the authority to use and enjoy income without being contractually restricted to forward funds directly to the other party, then the party is the beneficial owner. The beneficial owner concept was intended to determine the party that has the right to apply the treaty, not as a general anti-avoidance rule that expands the concept and causes uncertainty. The beneficial owner concept did not experience significant changes. The change lies in the wording and the addition of several criteria that complement the beneficial owner concept. The tax treaty's aim was to prevent the imposition of double taxation (Kusuma, 2014).

Anthony (2013) examined the meaning of beneficial owner to prevent misuse of double tax avoidance agreements. His study stated that tax regulations in Indonesia, the United States, and People's Republic of China (RRC) relating to beneficial owners did not interpret the meaning of beneficial owner directly or with specific criteria. The WPLN determined that the benefits (i.e., income ) of a tax treaty were beneficial owners. This was a reasonable approach, because the definition of 
beneficial owner should not technically refer to that of any country's domestic regulations. Indonesia, the United States, and the People's Republic of China limit benefits in different ways. Indonesia uses a channel approach, an approach subject to tax, and a stock exchange profit approach, all of which must be fulfilled except for the stock exchange provision. The United States, which adopts all three of the provisions, requires that the WPLN fulfill one of them. Broadly speaking, the PRC uses the competent authority provision, where foreign taxpayers can only use the tax treaty's benefits if they have obtained permission from the tax authority regarding source of income. It can be concluded that Indonesia, the United States, and the People's Republic of China have similar procedures to prevent misuse of tax treaties. All three countries use criteria or factors that define beneficial ownership and also use the principle of substance over form in their interpretations of beneficial ownership (Tiono, 2013).

This study's research about beneficial ownership differs from that of previous studies. We incorporate indepth analysis about how to interpret the "beneficial owner" term. Using approaches derived from the OECD commentary, we determine whether or not an entity is a real beneficial owner. We also highlight why Indonesian companies create SPVs abroad, such as being able to issue global bonds and to trade these bonds on international stock exchanges. Another determinant is lower interest rates for beneficial owners This study hopes to provide legal advice to Indonesian companies and also provide input to the DGT, which analyzes whether or not an entity can be classified as a beneficial owner, given the OECD articles that limiting benefits (Rachmanto, 2010).

Previous studies focused on a developmental interpretation of the beneficial owner term and also clarified how an entity could be categorized as an actual beneficial owner. This study focuses more on the tax court ruling between PT PLN and DGT and also examines in depth how the beneficial owner term is interpreted.

B. The OECD's Commentary about Limitations on Benefits

Previous studies conducted by Setyawan (2007) concluded that the leading cause of treaty shopping was the absence of clear definitions and criteria regarding the meaning of the term "beneficial owner" or articles regarding limitations of benefits that explain which parties are entitled to gain from tax treaties. Another study, conducted by Lelyemin (2009), concluded that beneficial owner rules already existed in Indonesia, in Article 26 of Income Tax Law Number 36 of 2008 and SE-03 / PJ / 2008. However, because the regulation did not regulate beneficial owners, it needs further improvement (Setyawan, 2007; OECD, 2011; OECD, 2017).

In a commentary section, the OECD suggested several forms of LOB (Limitation on Benefit) approaches (OECD, 2010), namely (Yoshimura, 2013):

\subsubsection{The Look-Through Approach}

Under this approach, a company can enjoy a tax treaty tariff if it is owned or controlled by residents of the country where the company was established. For example, if Company $\mathrm{X}$ were established in country $\mathrm{Y}$, it must be owned or controlled by the population of country $\mathrm{Y}$.

\subsubsection{The Subject- to-Tax Approach}

Under this approach, treaties' tax benefits are deemed to exist in the country where the income originates. If income originates in country $\mathrm{X}$, the taxation rights are also in country $X$.

\subsubsection{The Channel Approach}

Under this approach, when a third-state resident has a substantial interest in the recipient, or has management control over the recipient, if a state resident, a tax treaty's benefits can be applied if the income received is not forwarded to a third party but is used and controlled by the company. For example, when income coming from $\mathrm{X}$ in country $\mathrm{Y}$ is brought back to Country $\mathrm{Z}$, treaty benefits are not allowed.

\subsubsection{The Bona Fide Provision}

If provisions reflecting the above approaches are applied, unreasonable results could result, such as denying benefits to bona fide business transactions, thus discouraging legitimate business activities. Through this approach, it was stated that the company must have assets, management, employees/employees, or business transactions.

\subsubsection{The Activity Provision}

Under this provision, the state and the income must be related to operations. Through this approach, it was stated that a company must have a clear business substance. The income received must be income related to the type of business carried out. Revenue cannot only be sourced from passive income; it must include active income from actual business operations. 


\subsubsection{Amount of the Tax Provision}

Under this provision, a company is allowed to enjoy the tax benefits. The tax rate paid in the selected country must be equal to or higher than the tax rate of the country from which the income is sourced.

\subsubsection{The Alternative Relief Provision}

Under this provision, a resident of [a third state that has a tax treaty with the residence state] will not be considered a non-resident for residence claims, and "The tax treaty rates between the two countries that transact should not be lower or get other facilities that exceed if compared to other countries that also use the tax treaty with one of the countries that transact.

\subsubsection{The Stock Exchange Provision}

Under this provision, a company can enjoy tax benefits if it is listed on the stock exchange of the residence state. "The residence was listed on the stock exchange in the residence state." Through this approach, a company can enjoy the benefits of a tax treaty if its shares are listed on the stock exchange of the country where the company was established. For instance, companies established in Country X must be listed on a stock exchange in Country $\mathrm{X}$.

\subsubsection{The Competent Authority Provision}

Under this provision, a treaty's benefits can be enjoyed if the state tax authority adjudicating the source of income has given the SPV power to obtain these benefits.

\section{RESEARCH METHOD}

\subsection{Research Approach}

This research was conducted using a case study approach, using various data sources (data triangulation).

\subsection{Case Study}

Burton (2000) defined a case study as an in-depth, detailed testing of one setting, subject, document, or event. Surachnad (2004) noted that a case study focuses attention on a case intensively and in detail. According to Yin (2003), the case study approach can be used under three conditions: 1) when the types of questions raised in a study are how and why, 2) when the number of researchers are few, and researchers have no control over the events studied, and 3) when a study focuses on contemporary developments in real-life contexts. According to Yin (2003), the case study approach provides a broad and holistic understanding of complex issues, phenomena, or objects. (Our research is a case study). Researchers chose case studies for PT PLN and other companies because the Directorate General of Taxes (DGT) opined that interpreting the term "beneficial owner" can only be answered through case studies. Case studies allow researchers to dig deeper into tax authorities' information. Taxpayers differ in how they interpret the term "beneficial owner" and in what these interpretations imply for corporate global bond issuance.

\subsection{Qualitative Method}

This study uses a qualitative method. Moleong (2010: 6) defined qualitative research as research that attempts to understand what is experienced by research subjects, such as behavior, perception, motivation, and action. The use of a qualitative research method helps researchers collect information related to a beneficial owner's interpretation. However, this often causes disputes between taxpayers and DGT. Indonesian entities also tend to establish SPVs abroad to issue global bonds.

Qualitative methods are used because they thoroughly describe actual situations in Indonesian cases that relate to the beneficial owner, in particular regarding court decisions between PT PLN and DGT. Because the capital market in Indonesia is inadequate, this qualitative method also gives a clear picture of how companies in Indonesia form SPVs abroad to issue debt traded in international markets.

The data collected was processed systematically, beginning with interviews and continuing with an analysis of court decisions between PLN and DGT, beneficial ownership regulations in Indonesia, and similar cases in Indonesia, followed by a conclusion.

\subsection{The Triangulation Method}

This research uses a triangulation method, a qualitative approach that combines interviews and literature studies. According to Denzin (1978), within-method triangulation means using only qualitative or quantitative methods. Research that combines qualitative and quantitative research is called between-method triangulation. Denzin also mentioned that data triangulation uses various data sources. Because this study uses interviews and documents data that can prove if the information provided in interviews was correct, its approach is qualitative.

\subsection{Analysis Unit}

An analysis unit is the specific subject of the research. This study uses a single case study approach, applied to a 
single unit, focusing on one phenomenon or one case at a time. Here, we examine different interpretations of the term "beneficial owner" by Indonesian tax authorities (DGT) and taxpayers (PT PLN). Because it deals with Indonesian tax provisions, this has implications for companies' issuance of global bonds.

\subsection{Data Collection}

Data collection in this study produces two types of data, as follows:

\subsubsection{Primary Data}

Lofland, in Moleong (2010: 157), suggests that the primary data source in qualitative research is words and actions, which can be obtained from field interviews. We interviewed the State Electricity Company PT, which directly handled the court case between PT PLN and DGT regarding interest payments made to Majapahit Holding BV (namely, the verdict of the Supreme Court of the Republic of Indonesia Number 133 / B / PK / PJK / 2017). The interview was conducted on Wednesday, December 19, 2018, with Mr. Agus Saifullah Nur A.M., SE., M.Sc., SH., MH., Akt., CA from the Division of Accounting Sb in the Field of Tax Management in charge of Tax Inspection and Litigation. Based on this interview, information was obtained about how DGT corrected interest payments made to Majapahit Holding BV in the Netherlands. According to the DGT, MHBV was an SPV formed by PLN and should not be able to enjoy the Indonesian tax treaty. The informant also conveyed an argument suggesting that PLN could win the case, because the interpretation of "beneficial owner" should refer to international and not domestic regulations. Because "beneficial owner" is an international term, it was not included in Article 3 Paragraph (2) P3B. The interpretation must refer to the object and purpose of the $\mathrm{P} 3 \mathrm{~B}$ as a whole. This was accomplished by considering the provisions in the intended $\mathrm{P} 3 \mathrm{~B}$.

\subsubsection{Secondary Data}

Secondary data was data obtained from the literature and various other sources, such as OECD commentary models Articles 10, 11, and 12, journals, expert opinions regarding the term "beneficial owner", literature about beneficial owners, tax laws in Indonesia (namely, Regulation of the Director General of Taxes Numbers Per61 / PJ / 2009, Per-62 / PJ / 2009, Per-24 / PJ / 2010, and PER-25 / PJ / 2010). Note that all these regulations have been revoked and replaced with PER-10 / PJ / 2017, per the Supreme Court of the Republic of Indonesia's decision Number 133 / B / PK / PJK / 2017, between PT
Perusahaan Lwastrik Negara and the Directorate General of Taxes.

\subsection{Data Analysis}

Data analysis means parsing, sorting, and distinguishing in detail. According to Arikunto (2010), though, processing and analyzing data are different. Processing data means configuring raw data into meaningful data, from which ensues data analysis. Our data analysis consists of content analysis, comparative analysis, and descriptive analysis.

Content analysis allows researchers to analyze words to better understand the data (Elo and Kyngas, 2007). In this study, content analysis is used to analyze the results of court decisions, regulations relating to beneficial owners, journals that discuss beneficial owners, and the issuance of global bonds in Indonesia. Through content analysis, the Supreme Court's interpretation of the term "beneficial owner" was disclosed to PT PLN and the DGT. Content analysis also determines how to interpret the term "beneficial owner". It should refer to the existing approach in OECD commentary articles regarding limitations on benefits (LOB). The comparative analysis compares several studies' findings about how companies issue bonds abroad to obtain recognition of their shares. Descriptive analysis is used to describe problems and to research findings. The problem is to understand and interpret the term "beneficial owner", in particular, Indonesian companies interest in inexpensive, efficient funding that includes tax savings.

\section{RESULT AND DISCUSSION}

\subsection{Interpretation of Beneficial Owner, according to PER-10 / PJ / 2017}

According to PER Tax Directorate Number, PER-10 / PJ / 2017, WPLN meets the criteria of a beneficial owner if:

1. WPLN individuals do not act as agents or nominees

2. WPLN agencies do not act as agents or nominees and meet the following conditions:

a. Control and use funds or assets originating in Indonesia

b. All income based on non-consolidated financial statements used to fulfill the obligations of other parties cannot be more than $50 \%$ and does not include compensation to employees, usual costs, and dividends distributed to shareholders. 
c. They bear the risk of the funds and assets they own.

d. There is no obligation to distribute income from Indonesia to other parties.

As stated in the P3B, whether or not WPLN is the beneficial owner needs to be investigated by ensuring that the SKD (Certificate of Domicile) Form DGT-1 lists the answers:

1. "Yes" in Part V, Item 5 or

2. "Yes" in Part VII, Item 1, or

3. "No" for one or all of the questions in Part VII, Items 2 through 4 , or

4. "Yes" in Part VII, Item 5.

The tax rate, based on the tax treaty, cannot be applied if the WPLN answers one of the statements according to the above (Jendral Pajak Nomor, 2017).

Analysis of Beneficial Owners Using OECD Commentary about Limitations on Benefits (LOB)

To analyze whether or not Majapahit Holding BV (MHBV) is a beneficial owner can be proven by the following approaches:

\subsubsection{The Look-Through Approach}

This approach states that a company can enjoy tax treaty rates if it is owned or controlled by the population of the country where it was established. Based on the trial's facts, PT PLN was established as Majapahit Holding BV in the Netherlands, with $100 \%$ of its shares owned by PT PLN. Majapahit Holding BV also established Majapahit Finance BV in the Netherlands, with $100 \%$ of its shares owned by Majapahit Holding BV. Thus, both Majapahit Holding BV and Majapahit Finance BV are directly and indirectly owned by PT PLN. In other words, the appellant controls both Majapahit Holding BV and Majapahit Finance BV.

\subsubsection{The Subject-to-Tax Approach}

This approach states that an entity can enjoy the benefits of a tax treaty if it is taxed in the country where its income originates, and if the recipient of income is a resident of a $\mathrm{P} 3 \mathrm{~B}$ partner country taxed in that country. A confirmation letter, written by the Dutch tax authority, acknowledges that taxation of interest takes place in the Netherlands. Therefore, Indonesian taxes cannot be credited in the Netherlands. Interest income received by MFBV from the petitioner for judgment was taxed in the Netherlands. According to Article 26, the respondent's petition also imposes a withholding tariff of $20 \%$. Also per Article 26, the Netherlands tax authority does not allow crediting of income tax in the Netherlands. If taxes already paid in the Netherlands were imposed, this would result in double taxation, which would substantiate the Petitioner for Judicial Review's claim of injustice.

\subsubsection{The Channel Approach}

Through this approach, tax treaty benefits can be applied if income received is not forwarded to a third party but instead is used and controlled by the company. For example, if income from country $\mathrm{X}$ were transferred to country $\mathrm{Y}$ and then brought back to Country $\mathrm{Z}$, this would void the treaty. The facts of the case found that MFBV was owned $100 \%$ by MHBV and that MFBV made relatively small and insignificant payments to third parties (such as management, administrative, service, and audit fees). Here, MFBV did not make "back to back" payments ([transactions where MFBV gets interested from the Reviewing Applicant then the same amount or a large portion of the interest income was repaid by MFBV as interest or service/royalty fees to the party other]).

\subsubsection{The Bona Fide Provision}

In this approach, an established company must have assets, management, employees, or business transactions. In the trial, DGT revealed the following:

Majapahit Holding BV and Majapahit Finance BV did not have employees who carried out company operations, so there were no employee remunerations.

The person who signed the same financial management report for Majapahit Holding BV and Majapahit Finance BV was Member A (Mr. A. Hakam) and Member B (Deutsche International Trust Company NV), who was an employee of the appellant.

Majapahit Holding BV, Majapahit Finance BV, and Deutsche International Trust Company N.V. have the same address: Herengracht 450, 1017CA Amsterdam. Most of the funds obtained from bonds issued by Majapahit Holding BV were immediately channeled to Majapahit Finance BV and received as interest income, almost equal to that from Majapahit Finance BV to Majapahit Holding BV.

Over $90 \%$ of Majapahit Holding BV's expenses were interest costs, with the additional $10 \%$ being operating expenses.

MHBV, therefore, was not considered a beneficial owner, because it conducted no business activity, .which would have been the case if MHBV were a financial 
center. This suggests that MHBV was not a bona fide entity.

\subsubsection{The Activity Provision}

The court stated that a company must have a clear business substance, and that income received must be related to a business. Revenue must be sourced from an active entity with real business operations. The facts showed that MHBV did not show significant business activities. There were no salary payments tor professional employees, assets, or purchases or sales related to the company's operations. Therefore, MHBV was not a real beneficial owner.

\subsubsection{The Amount of Tax Provision}

Taxes paid in the country of standing must be at least equal to the tax rate from the originating country. Indonesia, the source country, had an income tax rate of $20 \%$, subject to the Article 26 income tax law. In the Netherlands, the tax rate was only $10 \%$. Therefore, since the source country's tax rate was higher than that of the resident country, a tax treaty cannot be applied.

\subsubsection{The Alternative Relief Provision}

[Tax treaty rates between two countries that transact should not be lower or get other facilities that exceed if compared to other countries tax treaty rates that also utilize tax treaty with one of these countries]. If countries $\mathrm{X}, \mathrm{Y}$, and $\mathrm{Z}$ are subject to tax treaties, and $\mathrm{X}$ and $\mathrm{Y}$ 's tax rate is $10 \%$, then $\mathrm{Y}$ and $\mathrm{Z}$ cannot have a rate lower than $10 \%$. Y-Z treaty benefits cannot be smaller than those of $\mathrm{X}-\mathrm{Y}$, [and other facilities cannot exceed X-Y]. In the case being discussed here, a special feature in the IndonesiaDutch treaty was not found in a separate treaty. Article 11, Paragraph 4 states that one is taxed for interest on international bonds in the Netherlands issued by Majapahit Holding BV only if the beneficial owner of the interest is a resident of the Netherlands and if the debt agreement is for a period longer than two years. Because of these special features in the tax treaty between Indonesia and the Netherlands, P3B benefits were not available.

\subsubsection{The Stock Exchange Provision}

A company can enjoy the benefits of a tax treaty if it is listed on the stock exchange as an established company. In other words, companies established in Country X must be listed on a stock exchange in Country $\mathrm{X}$. Therefore, the MHBV enjoy the benefits of P3B only if its shares are listed on the Netherlands stock exchange. Because they are not, the court stated that the MHBV could not receive tax benefits from the Indonesia-Netherlands WUA.

\subsubsection{The Competent Authority Provision}

The tax treaty is legal only if a SPV has been approved by the Indonesian tax authority. Since MHBV's attempt to apply the P3B by MHBV was not approved by the Indonesian tax authorities, MHBV was not entitled to the treaty's tax benefits.

The above analysis tested whether or not MHBV was the real beneficial owner of PT PLN's interest payments. Only three approaches support this contention, namely, the look-through approach, the subject-to-tax approach, and the channel approach. All the others do not prove that MHBV can enjoy the benefits of the IndonesiaNetherlands Tax Treaty.

\section{CONCLUSION AND RECOMMENDATIONS}

\subsection{Conclusion}

The court determined that PT PLN and DGT were beneficial owners. This interpretation is defined by international rather than domestic regulations. Here, determination of the "beneficial owner" was based on the Indonesian-Netherlands tax treaty.

A beneficial owner's interpretation of the issuance of global, corporate bonds was based on several Indonesian cases dealing with the legality of forming SVPs abroad, particularly legal uncertainty. Because this clearly impacts how a company funds itself, it may need to look for other financing alternatives.

\subsection{Suggestions}

Based on the discussion of Chapter 4's results, we offer some suggestions:

1. Different interpretations of the term "beneficial owner" between the Directorate General of Taxes (DGT) and the State Electricity Company (PLN) in Indonesia are caused by regulations dealing with how to implement the Double Tax Avoidance Agreement in the Regulation of the Directorate General of Taxes Number Per 61 / PJ / 2009, Per-62 / PJ / 2009, Per-24 / PJ / 2010, and PER-25 / PJ / 2010. All of these regulations were revoked and replaced with PER-10 / PJ / 2017 through Form DGT-1. This form makes it impossible for PLN to answer whether or Majapahit Finance BV was a beneficial owner. The required DGT-1 form asks for yes or no answers, and this 
information was not detailed enough to prove whether or not Majapahit Finance BV was a real beneficial owner.

2. Due to the DGT-1 form's limitations, it was necessary to add an attachment to the latest regulation of the Directorate General of Taxes concerning implementing the Double Tax Avoidance Agreement, namely, PER-10 / PJ / 2017, which contains additional questions and documentation.

3. The documents referred to in the Attachment must include the following regarding beneficial ownership, as contained in Article 8 PER-10 / PJ / 2017:

A Financial Report consissting of a Financial Position Report, a Comprehensive Income Statement, a Change in Equity Report, a Cash Flow Report, and notes to financial statements for the current year.

A Company Agency SPT for the Current Year.

Proof of Payment of Foreign Taxes.

A Company Establishment Letter.

4. It is necessary to review tax treaties between Indonesia and other countries, to ensure that domestic tax regulations are complied with. Where a tax treaty is used to avoid taxes, this affects the Directorate General of Taxes' position because it weakens his argument in court. In addition, tax treaties between Indonesia and other countries should be uniform so that the privileges in the Indonesian-Dutch tax treaty (in Article 11, Paragraph 4) do not recur. Tax treaties with unusual privileges can be used to avoid tax payments.

5. Companies form SPVs abroad because Indonesia's capital markets lack sufficient capacity. This is likely to contine, possibly leading to more problems of legal interpretation. Motivated by corporate funding needs, a workable understand should be encouraged between companies and government tax regulations to improve the quality of Indonesian capital markets.

\section{REFERENCES}

[1] Brown, C. 2003. Symposium: beneficial ownership and the income tax act. Ottawa: Canadian Tax Journal, 51(1), 401-453.

[2] Darussalam. 2013. Beneficial ownership concept, history, and recent development. inside tax edissi 14 Danny Darussalam Tax Center, 34-35.

[3] Darussalam., Hutagaol, J., Septriadi, D. (2010). Konsep dan Aplikasi Perpajakan Internasional. Jakarta: PT Dimensi International Tax.
[4] Decision Court Number (Put15719/PP/M.VIII/13/2008)

[5] Decision Court Number PUT-23289/PP/M.II/13/2010

[6] Du Toit, C. P. (1999). Beneficial ownership of royalties in bilateral tax treaties. Amsterdam: IBFD Publication.

[7] Elo, S. and Kyngas, H. (2007) The Qualitative Content Analysis Process. Journal of Advanced Nursing, 62, 107-115.

[8] Kusuma, A. 2014.Analwaswas Perkembangan Konsep Beneficial Wwner Dalam Perjanjian Penghindaran Pajak Berganda OECD Model. Tesis Magiaster Akuntansi Universitas Indonesia.

[9] Lelyemin, M. L. 2009. Analwaswas Upaya Pencegahan Treaty Shopping melalui penentuan Beneficial Wwner. Universitas Indonesia.

[10] Meyer, S. P. 2010. The meaning of beneficial ownership and the use thereof for tax treaty shopping and tax avoidance. Pretoria, Greek: University of Pretoria.

[11] OECD. 2011. Clarification of the meaning of "Beneficial Owner" in the OECD Model Tax Convention. Centre for Tax Policy and Administration. Paris: OECD.

[12] OECD. 2017. Model tax convention on income and on capital. Paris: OECD

[13] Peraturan Direktur Jenderal Pajak Nomor PER10/PJ/2017 Tentang Tata cara Penerapan Persetujuan Penghindaran Pajak Berganda Direktur Jenderal Pajak.

[14] Purwijanti, P. 2018. Pengaturan Karakterwastik Beneficiary Owner di Indonesia. Universitas Airlangga.

[15] Rachmanto. 2010. Penentuan Beneficial Owner dalam Kasus Pembayaran Bunga oleh PT Transportasi Gas Indonesia kepada Transasia Pipeline Company PVT. LTD. Tesis Magister Akuntansi Universitas Indonesia.

[16] Setyawan, A. E. 2007. Analisis Penerapan Konsep Limitation on Benefits dalam Menentukan Beneficial Owner Sebagai Upaya Mencegah Praktek Treaty Abuse Melalui Pembentukan Special Purpose Vehicle Di Tax Heaven Country. Indonesia: Universitas Indonesia

[17] Tax Court Decision 05/Pdt.G/2003/PN.BKS Tanggal 13 November 2003 
[18] Tax Court Decision Number 133/B/PK/PJK/2017

[19] Tiono, A. 2013. Penentuan Beneficial Owner untuk Mencegah Penyalahgunaan Perjanjian Pajak Berganda. Universitas Krwasten Petra.

[20] Undang-undang Republik Indonesia Nomor 36 Tahun 32008 Tentang Perubahan Keempat Atas
Undang-Undang Nomor 7 Tahun 1983 Tentang Pajak Penghasilan.

[21] Yoshimura, K. 2013. Clarifying the meaning of 'Beneficial Owner' in tax treaties. New York: Tax Analist. 